\title{
手根管症候群における超音波検査と 神経伝導速度検査との比較
}

\author{
国立療養所刀根山病院整形外科 \\ 中井毅・平林伸 治 \\ 鍋 島 隆 治 \\ 大阪大学整形外科学教室 \\ 河 井 秀 夫
}

\section{Carpal Tunnel Syndrome; Ultrsonographic and Electrodiagnostic Studies}

\author{
by
}

\section{Tsuyoshi Nakai, Shinji Hirabayashi and Takaharu Nabeshima \\ Department of Orthopaedic Surgery \\ Toneyama National Hospital \\ Hideki Kawai \\ Department of Orthopedic Surgery, Osaka University School of Medicine}

\begin{abstract}
We studied thirteen hands of ten patients with carpal tunnel syndrome to elucidate the relationship between the degree of median nerve compression and distal motor latency. All patients underwent ultrasonographic and electrodiagnostic studies prior to operation. Intracarpal thickness of two portions of median nerve, proximal(A)and distal(B)to the position of carpal transverse ligament, were measured by ultrasonography, and the median nerve compression ratio was given by $\mathrm{B} / \mathrm{A}$. It was demonstrated that, in proportion to the degree of median nerve compression, there was a significant increase in distal motor latency of the damaged nerve.
\end{abstract}

はじめに

手根管症候群は, 整形外科疾患の中では日常的な疾 患であるが，適切な画像診断法がなかった， C T・M R I による診断は，放射線の被爆や費用などを考元る と必ずしも適切な検查法ではない. 超音波検査では, 正中神経, 手根管内の炎症, 腫崵の画像診断が可能で ある、今回われわれは, 超音波検査で得られる手根管 内での正中神経の圧迫程度と神経伝導速度検查（運動 終末潜時）との比較について検討した。

対象

臨床症状，神経伝導速度検査にて手根管症候群と診 断し, 手術治療した 20 例, 23 関節のうち, 正中神経の
厚さについて retrospective に評価可能であった 10 例(男 1 , 女 9 ), 13 関節である. 年齢は $34 \sim 76$ 才 (平 均 53.3) であった。

\section{方法}

超音波器械は, アロカ社 S S D-650, 東芝 S A L-38 Bで $10 \mathrm{MHz}$ と $7.5 \mathrm{MHz}$ のメカニカルセクター探触 子を使用した。

超音波検査は患者を坐位とし，手台を用い手関節を 掌屈・背屈中間位として手関節掌側より縦方向, 横方 向に探触子を走查した。

縦方向走查により得られた画像から正中神経の圧迫 の程度を, 手根管近位と圧迫されている遠位との正中 神経の厚さの比率（\%) で表し（図 1)，1～49\%, 
表 1 超音波検査で得られた正中神経の厚さ（\%)と 神経伝導速度（潜時）との関係

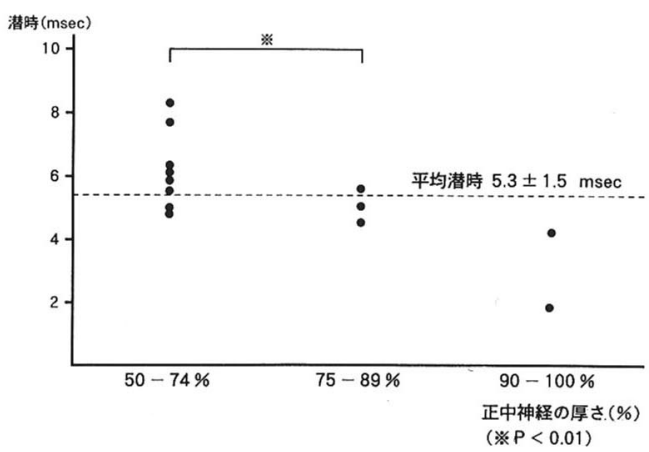

$M E D$

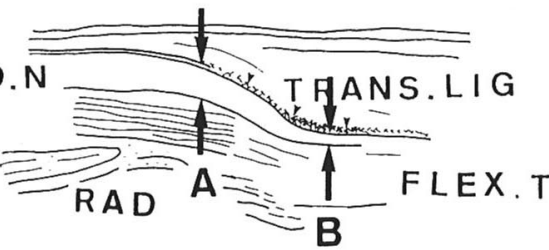

正中神経
厚さ
$\%=\mathrm{B}$

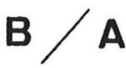

図 1 : 縦方向走查のシェーマ

正中神経の圧迫の程度を, 手根管近位と圧迫されて いる遠位との正中神経の厚さの比率（\%）で表した。
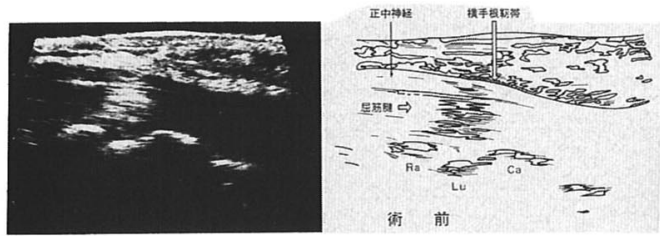

図 $2:$ 症例 1 の縦方向走查（術前）

正中神経は横手根勒帯により手根管遠位で圧迫を受 け, 厚さの比率は $90 \%$ \%でった。 また屈筋腱はやや 高エコーを示した。

50〜74\%，75〜89\%，90〜100\%の 4. 群に分けた。 圧迫の程度と運動神経伝導速度の終末潜時について比 較した。

$$
\text { 結果 }
$$

正常の被検者について超音波検査を実施すると，縦 方向走査では正中神経は隣接する屈筋腱より低エコー で索状に手根管内を平滑に走行する。神経に接して掌 側にある横手根鞄帯による圧迫は認めない。横手根靰

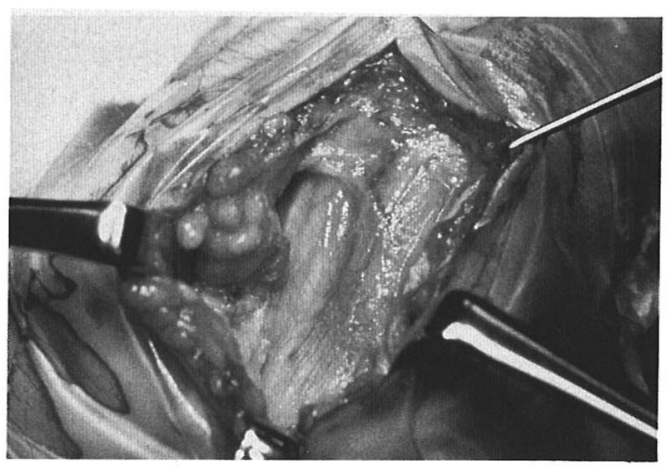

図 3：症例 1 の術中所見 横手根鞄帯の肥厚と同部での正中神経の偏平化およ び屈筋腱の滑膜の増殖がみられた。
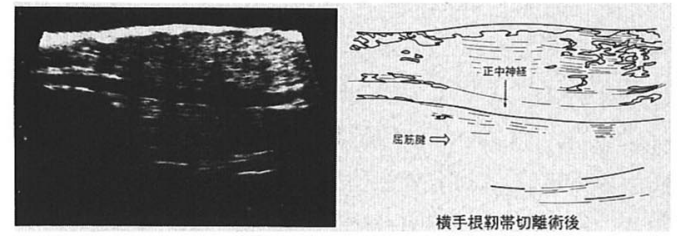

図 $4:$ 症例 1 の縦方向走査 (術後) 正中神経にたいする圧迫は消失し，走行は平滑にな っていた.

帯は手掌軟部組織とほぼ同じかやや高いエコーレベル を示す．横方向走查では屈筋腱は一塊となっており， 個々の腱を区別することは困難である。

正中神経が $49 \%$ 以下に圧迫された症例はなく， 50 74\%：8 関節，75 89\%：3 関節，90 100\%： 2 関節であった。運動神経伝導速度の終末潜時は，正 中神経の厚さの比率が 90〜100\%では平均 $2.9 \pm 1.1$ msec, $75 \sim 89 \%$ では平均 $5.0 \pm 0.4 \mathrm{msec}, 50 \sim 74 \%$ で は平均 $6.0 \pm 1.2 \mathrm{msec}$ と圧迫の程度が強くなるに従 い有意 $(\mathrm{p}<0.01)$ に延長した。平均潜時は $5.3 \pm 1.5$ msecであった（表 1 )。

症例 $1: 69$ 才 女性. 主訴は左示.中指の夜間痛, しびれ感であった. Tinel 症候はみられたが, 母指球筋 の菱縮は認めなかった。 術前の縦方向走查では, 正中 神経は横手根勒帯により手根管遠位で圧迫を受け, 厚 さの比率は 90 \%であった。また屈筋腱はやや高エコー を示した(図 2). 横方向走査ではやや高エコーの横手 根勒帯を認め, 正中神経は偏平化していた。

この症例に対して横手根勒帯の切離を行った. 正中 
神経は手根管遠位において肥厚した横手根勒帯によつ て圧迫され，扁平化していた，偽神経腫はみられなか った。屈筋腱の滑膜は増殖し, 背側より正中神経を圧 迫していた（図 3 ).

術後の縦方向走査では圧迫が消失し正中神経の走行 は平滑になっていた (図 4)，横方向走查では正中神経 は除圧されていた, 術後左示・中指の疼痛, しびれ感 は消失した。

\section{考察}

手根管症候群における超音波検査の有用性はすでに 報告した。運動終末潜時が手根管症候群の診断・手術 適応の指標として有用であるという報告がある112). 今 回は正中神経の圧迫程度と運動終末潜時とについて比 較・検討を行った。運動終末潜時は正中神経の厚さの 比率が低下つまり圧迫の程度が強くなるに従い有意に 延長した。 われわれは超音波検査で得られる正中神経 の形態学的変化と電気生理学的変化との相関を認めた ため，今後さらに症例を検討し超音波検査を手根管症 候群の手術適応の指標として用いたいと考えている.

\section{ま と め}

1 ，綐方向走査により得られた画像から正中神経の 圧迫の程度を，手根管近位と圧迫されている遠位との 正中神経の厚さの比率（\%）で表し，圧迫の程度と運 動神経伝導速度の終末潜時について比較した。

2 , 神経の圧迫の程度が強くなるに従い終末潜時は 延長していた。

\section{参 考 文 献}

1）内田芳雄 : 手根管症候群の治療, 整・災外，34：975 $-979,1991$.

2）堀内行雄 - 他：手根管症候群と尺骨神経管症候群 (Guyon 管症候群) の診断と治療, MB Orthop. , 22 : 13-22, 1990.

質 問佐賀医科大学 上田 淳

(1) 正常例では手根管内と，その近位部の正中神経の エコー上の厚さの比は $100 \%$ なのでしょうか?

(2) 実際のエコー実施の時は，ゲル以外に介在物は必 要なかったでしょうか?

解 答 刀根山病院 中井 毅

(1) $100 \%$ 末満である.

(2) 介在物はゲルのみであった.

質 問琉球大学 新垣 晃

(1) 正常人での計測が必要ではないでしょうか.

(2) 超音波で得られたデータと実際の手術時の所見 (実測) との差はどの程度あったのでしょうか.

解 答 刀根山病院 中井 毅

(1) 今後計測する予定である.

(2) 今回は検討していないため, 今後検討させて頂き ます。 